\title{
Linen, Silver, Slaves, and Coffee: A Spatial Approach to Central Europe's Entanglements with the Atlantic Economy
}

\author{
Klaus Weber \\ European University Viadrina \\ Große Scharrnstraße 59,D - 15230 Frankfurt (Oder) \\ e-mail: weber@europa-uni.de
}

Submitted: 5 September 2014. Accepted: 1 June 2015

\begin{abstract}
In German scholarship of the post-war period, the category of space was regarded as discredited, because of its abuse during the Nazi period. This applies in particular to the 1970s and 80s, when novel approaches in social and economic history were developed. Research on proto-industrialisation, broadly examining its internal structures, did not take into account the export orientation of Central Europe's early modern commodity production. At the same time, the expanding research on Europe's Atlantic empires, including the trans-Atlantic slave trade, did hardly take notice of the manufactures from the Holy Roman Empire, distributed all around the Atlantic basin. This paper examines those conditions favouring German proto-industries which are relevant for a 'spatial approach' to the phenomenon. It also covers the late medieval beginnings of this process, in order to demonstrate the continuity of Central Europe's entanglement with the Atlantic world. The paper further emphasises that any future research using spatial categories must be aware of the ideological contamination of the German term 'Raum' during the $19^{\text {th }}$ and $20^{\text {th }}$ century. The interlace of economic and social history with historiography demands a compilation from current and older research literature, some of it on different regions and subjects.
\end{abstract}

KEYWORDS: $18^{\text {th }}$ Century; Central Europe; Spanish America; proto-industries; textile trade; trans-Atlantic slave trade

Citation / Cómo citar este artículo: Weber, Klaus (2015) "Linen, Silver, Slaves, and Coffee: A Spatial Approach to Central Europe's Entanglements with the Atlantic Economy". Culture \& History Digital Journal, 4(2): e020. doi: http://dx.doi. org/10.3989/chdj.2015.020

RESUMEN: Lino, plata, esclavos y café: un enfoque espacial para estudiar los entramados de Europa Central con la economía Atlántica.- En la escuela alemana del período de pos-guerra la categoría de espacio fue desprestigiada debido a los abusos sucedidos durante el período nazi. Esto se aplica en especial a los años de 1970 y 1980, cuando se desarrollaron los nuevos enfoques en historia social y económica. Las investigaciones sobre la proto-industrialización en Europa Central durante la Edad Moderna que examinan, en líneas generales, sus estructuras internas, no tuvieron en cuenta la dimensión espacial de las exportaciones de su producción. Al mismo tiempo, las crecientes investigaciones de los imperios europeos en el Atlántico, incluso del comercio de esclavos transatlántico, no hacen referencia a las manufacturas del Sacro Imperio Romano Germánico, distribuidas todas alrededor de la cuenca del Atlántico. El trabajo examina aquellas condiciones favorables de la proto-industria alemana que son relevantes para un 'spatial approach' (enfoque espacial) del fenómeno. También incluye los inicios de este proceso en la Baja Edad Media con el fin de demostrar la continuidad de los entramados de Europa Central con el mundo atlántico. El estudio hace énfasis en la idea de que cualquier investigación futura usando categorías espaciales debe tener en cuenta la contaminación ideológica del término alemán 'Raum' durante los siglos XIX y XX. El entrelazado de la historia económica y social con la historiografía ha exigido una compilación de literatura investigativa tradicional y actual, alguna de ellas en diferentes regiones y temáticas.

PALABRAS CLAVE: Siglo XVIII; Europa Central; Hispanoamérica; proto-industrias; comercio textil; trata transatlántica.

Copyright: (C) 2015 CSIC This is an open-access article distributed under the terms of the Creative Commons AttributionNon Commercial (by-nc) Spain 3.0 License. 
"While $19^{\text {th }}$-century authors like Schmoller and Droysen wished to shape politics, the geographer Erich Obst (1886-1981) quarrelled with topography. ... ...... Obst regarded it as a proof of political intelligence that the Soviet government abandoned St. Petersburg, and turned back to Moscow as the traditional and best-suited capital of the empire (Obst, 1928, 30)."

In current overviews on the 'spatial turn', American and French scholars are mentioned as leading figures which inspired humanities for (re-)discovering space as a category worth considering, from the perspectives of sociology, history, anthropology, and so forth. Among them, Henri Lefebvre (1901-1991) and Edward W. Soja (*1940) are figuring prominently (Lefebvre, 1974; Soja, 1989). Yet, behind those $20^{\text {th }}$ and $21^{\text {st }}$ century authors, there are a few German scholars who have made space their central category already during the $19^{\text {th }}$ century. Karl Schlögel has already alluded to these prominent German harbingers (Schlögel, 2003: 36-47). These earlier authors' interest in space and geography was much inspired by romanticism, e.g. by the writing of Johann Gottfried Herder and his emphasis on the particularity of each culture, which he saw shaped by its respective language, but also by the geographical space of its homelands, with its particular climate and soil, and consequently agriculture, architecture etc. Impregnated with such romanticist views was Carl Ritter (1779-1859), one of the pioneers of modern geography. His interest was not so much in physical geography, but rather on the mutual influences between mankind ('culture') on the in hand, and nature (or the environment) on the other - thus anticipating the modern challenge of pre-assumptions about the dichotomy between man and nature. Ritter was also much interested in change over time, thus in historical geography. Such ideas were modified in the course of the $19^{\text {th }}$ century, notably by Friedrich Ratzel (1844-1904), a zoologist. This background explains the influence of Charles Darwin's theories, and their (mis-)interpretations in Social Darwinism, on his writing. Ratzel adopted biologist concepts for the description and analysis of political entities, and he compared the development of states with the biology of organisms. For the expansion and shrinking of states and of their territories he formulated a 'law of expanding spaces' (Gesetz der wachsenden Räume), and thus provided a theoretical blue-print for the colonial and naval policy of Imperial Germany. Ratzel's ideas were further adapted by the geographer Karl Haushofer (1869-1946), who made a military career. From 1908 to 1910 the German Imperial army sent him to China and Japan, where he studied the Japanese military and advised it as an artillery instructor. During the First World War, he rose to the rank of a General. Haushofer coined the term 'Geopolitik', which became important in Japanese military planning (Geopolitik des Pazifischen Ozeans, 1925), and which became a key word in the expansionist discourse of Nazi Germany (Bausteine zur Geopolitik, Berlin 1928; Geopolitische Grundlagen, Berlin/Wien 1939). Like Ratzel, he adopted concepts from biology, most notoriously the term 'Le- bensraum', understood as the living space which one people may defend against competing peoples and nations. Haushofer also held important posts during the Third Reich, and became one of the most prominent inspirers of the Nazi ideology of the very 'Lebensraum' which the German army was to conquer in Eastern Europe. Thus, Karl Schlögel states that such contamination made the German term 'Raum' a taboo (Schlögel, 2003: 52).

This brief detour is only meant to explain why in the post-war German-speaking world in particular, 'space' was a highly discredited term in research for decades. The younger German and Austrian historians of the 1970s and 80s emphasised social history, even more than their colleagues in other European countries. Their major focus was on the internal structures and developments of societies, or rather of societal orders. This may also help to explain why the French School on the Annales, in particular its early phase, which was much shaped by Fernand Braudel and his own thinking in spatial categories, was never much appreciated among this generation of German historians. The broader interest of French historians in the category of space was institutionalised: Their academic discipline has always been closely intertwined with geography, e.g. by the creation of chairs combining history and geography (Holt-Jensen, 2004: 45-48). An example of the German post-war disinterest in geography and space is provided by the prominent and most commendable works on Central European proto-industries. Peter Kriedte's, Hans Medick's and Jürgen Schlumbohm's collective book on "Industrialization before Industrialization", and Hans Medick's case study on a Swabian linen weaving village - both of them masterly works - do illustrate this constraint (Kriedte and Medick and Schlumbohm, 1981; Medick, 1997). This also applies to the volume co-published by the Austrian historian Markus Cerman (Cerman and Ogilvie, 1996), and more such examples could be provided. The lack of geographical considerations or spatial approaches in these studies is even more surprising as their very subject - proto-industries - could only thrive because they were export-orientated. This is the aspect which makes Central European commodity production relevant to the topical issue of space from an early modern Spanish, and from a wider Atlantic perspective.

In order to find systematic overviews on the exportorientation of German —or Central European - commodity production, one needs to refer to scholarship from the generation that started its career during the 1930s and 1940 s, e.g. to Wolfgang Zorn's exhaustive article on the export industries in the Holy Roman Empire of the $18^{\text {th }}$ century (Zorn, 1961: 421-447), or to the overview on the Empire's foreign trade of the same period, provided by Hermann Kellenbenz (Kellenbenz, 1964). The articles by these authors from Western Germany are complemented with a publication by the Eastern German historian Manfred Kossok, who examined the importance of the Spanish-American colonial markets for the linen trade from Prussian territories during the late $18^{\text {th }}$ and early $19^{\text {th }}$ centuries (Kossok, 1961). The geographical awareness of 
both Kellenbenz and Kossok demonstrates that at their time, this was not a question of ideology: Hermann Kellenbenz (1913-1990) started his career as a researcher at the 'Reichsinstitut für Geschichte des neuen Deutschlands', created in 1935 explicitly for writing the history of the 'new' Germany which was just in the making (Heiber, 1966: 452-57, 1189). Manfred Kossok (19301993), in contrast, was one of the leading social historians in the German Democratic Republic. What they had in common was that they did not bother to deal with the category of space, much in contrast with most of the protagonists of the following generation. Kossok and Kellenbenz are also interesting figures as they trained the few younger historians in East and West Germany who had German maritime trade and respective markets on their agenda: Hans Pohl, Otto-Ernst Krawehl and Jürgen Schneider (Pohl, 1963; Krawehl, 1977; Schneider, 1998; Schneider, Krawehl and Denzel, 2001), to name but a few of Kellenbenz' scholars, and more notably Kossok's scholar Michael Zeuske (Zeuske, 1995; Zeuske and Ludwig, 1995).

If post-war scholarship in the German-speaking world has been much concerned with the internal structures of proto-industrialization, and hardly considered the distant markets and the importance of Central European commodities in the Atlantic economies, scholars in Atlantic history did not take into account how much commodity production in Central Europe was a part of the wider Atlantic world. Only a few historians have considered Europe's more Eastern hinterlands. Immanuel Wallerstein has widely acknowledged the importance of wheat exports from the agrarian regions east of the River Elbe to Western Europe (Wallerstein, 1974); Zsigmond Pal Pach looked at a wider range of commodities traded between East-Central Europe and the western hemisphere (Pach, 1990). The neglect of manufactured commodities from Central Europe is illustrated only by scrutinising literature on production and consumption of textiles. This product is relevant in so far as textile production was a key industry all over the early modern world, not only in Europe. Further, fabrics of all sorts were the most important merchandise in the barter trade for African slaves - and they were important also outside this sector of colonial commerce. Throughout the four centuries of the trans-Atlantic slave trade, textiles made up for c. 50 per cent of the value shipped to Africa. With regards to the Northern Atlantic world, Leslie Clarkson states that cotton, originally an 'exotic' product, figures most prominently in all the relevant literature, as a commodity which Europeans have always desired, which has been prominent in early intercontinental trade (including in the barter trade for African slaves), in the slave-based economy of the US South, and in the Industrial Revolution in Great Britain (Clarkson, 2003: 473-475; Riello and Parthasarathi, 2009; Beckert, 2014). At the same time, she concludes, that the autochthonous linen has been almost entirely omitted by the scholars - although the fabric was ubiquitous in Europe, for clothing, bedding, tablecloth, packaging, canvas, etc. Even a more recent essay collection on the European linen industry treats mostly British, Irish and North American aspects, and hazards some views into Sweden, Belgium and $19^{\text {th }}$-century Germany (when linen was already in irreversible decline) - but the omnipresent linen trade of $17^{\text {th }}$ and $18^{\text {th }}$-century Northern France and Central Europe has been ignored to the full (Collins and Ollerenshaw, 2003). Its importance has been taken into account by a number of German scholars, but their studies on some particular textile regions, published in the German language, did not have the impact they would have deserved (Boldorf, 2006; Flügel, 1993; Niemann, 2004).

It is true that the home-spun linen lacks the glamour of silk, the ornaments and the brilliant colors of calicoes, and the dignity of a woolen cloth, but in spite of all its inconspicuousness it was one of the products which did closely link the peoples around the Atlantic basin with those in Atlantic hinterlands, and it did so over centuries. This history of linen can very well illustrate how distant regions established trade relations and thus constituted a wider, previously nonexistent socio-economic and cultural space.

The integration of early modern German lands into the western hemisphere has thus long been underestimated. A first synthesis which took into account not only the linen trade and its Atlantic dimensions, but also the consumption of colonial produce, which spread namely in $18^{\text {th }}$-century proto-industrial regions, has been provided by Michael Zeuske and Jörg Ludwig (Zeuske and Ludwig, 1995). This essay shall substantiate their portrait of the close entanglements of Central Europe with the Atlantic world. It will do so by summarizing studies which covered the earlier phases, and results from more recent research on the $18^{\text {th }}$ century. It will also consider parameters such as labour supply and labour cost, their differentials among different regions, climate, soil and ores as resources for agriculture and industry, and geography, in particular with regards to transport routes.

\section{LINEN AND TRADE IN LATE MEDIEVAL SOUTHERN GERMANY}

In contrast with cotton, which is the world-wide prevailing fabric today, the raw material for linen had always been a European home-grown fibre (Jenkins, 2003). The soil and moist climate of Normandy, Wallonia, the Champagne, the Rhineland, Westphalia, Northern Switzerland, Swabia and Franconia, and of many Polish and Russian regions offer favourable conditions for growing flax. The local population was available for spinning the yarn and weaving the cloth at relatively low costs. The finished fabric is very appropriate to wear in hot climate, in particular for those who have to perform physical labour. This particular comfort and the lower price distinguishes it from woollens, as Europe's more sturdy textile, and these two features made linen an ideal item for markets in the Mediterranean world, including Northern Africa (Aubin and Kunze, 1940: 1-5). 
Towns and countryside in Upper Germany ('Oberdeutschland' is the old name for Southern Germany) and Swiss German regions lived the heyday of their linen export trades from about 1300 to 1500 . Powerful dynasties of industrialists and financiers, such as the Fugger, Welser and Höchstetter from Augsburg, and the Viatis and Peller from Nuremberg, emerged from this world. New merchant companies like the Ravensburger Handelskompanie (created in the 1380s in the town of Ravensburg, just a few miles north of Lake Constance) coordinated capital, labour, and the wide-reaching networks for distributing the region's finished fabrics (Schulte, 1923). During the $15^{\text {th }}$ century, the city of Ulm and its hinterland alone produced up to 100,000 pieces of linen annually (with figures declining by 1550) (Kellenbenz and Walter, 1986: 862). Much of the spinning and weaving was organised in a cottage industry which employed the cheaper rural labour. Emporiums of this export trade were Venice and Genoa, where German merchants had established their own permanent communities.

German lands, in turn, imported highly appreciated oriental products, which Italians brought from the Levant: spices, cotton, silk, dyes, sugar, etc. Much of the imported cotton was combined with local linen thread and woven into fustians (German term: 'Barchent'). Spices such as nutmeg, cardamom, clove, pimento and cinnamon were used not only for hearty cooking, but also for the rather sweet Christmas pastries from Saxony and Nuremberg. Even today the ingredients in those traditional recipes still hint at the medieval city's connections with the Levant.

Such imports were paid for with the export of linen from German lands. Yet, the fabric could not be bartered directly against oriental products. While Asians considered occidental textiles and most other European manufactures primitive and coarse, Europe was better provided with occurrence of gold and silver than the East. Arab and Indian merchants therefore demanded bullion in exchange for their own export commodities. Even though precious metals were mined in the Massif Central, in the Tyrol Alps, in Southern Saxony and Bohemia, in Hungary and other places, the European deficit in medieval Levant trade had to be balanced with additional imports of gold from Africa (Bloch, 1933: 1-34; Braudel, 1946: 9-22). Exportation of textiles to Africa was one of the means to obtain some of the gold which was produced in Western Sudan and on the Gold Coast (today Ghana), and brought by trans-Sahara caravans to the northern regions of the African continent. Linen exports from Central Europe certainly contributed to pay for the total of supplies from Africa (Małowist, 2009c [originally published in 1968]: 386; 2009b [originally published in 1968]: 345; 2009a [originally published in 1973]: 133). If Africans were well supplied with bullion, they were lacking iron and copper ores. A wide variety of European iron and brassware was therefore to become an important complement to the textiles, as soon as Portuguese shipping lanes were extended far enough south to allow for a bulk trade with Africa.
A basic pattern of late medieval Central Europe's foreign trade was: export of linen and brassware to the South, in order to obtain gold; and expenditure of this gold for Oriental produce.

\section{A GERMAN EXPANSION INTO THE ATLANTIC?}

Portuguese maritime expeditions had reached Madeira by 1419 , the Cabo Verde by 1444, the Gold Coast by 1471 , and the Congo and Angola coasts during the 1480s. From the 1470 s, they created large sugar plantations on the islands of São Tomé and Príncipe, in the Gulf of Guinea. There is no need here to go deeper into how the Portuguese combined their quest for gold with the exploration of the direct sea route to India, where this gold was to be spent for Oriental commodities. As mentioned above: Asia was no market for European commodities. More relevant in the context of this essay is the Iberian expansion into the Atlantic world, and the slave trade which it engendered. The forced migration of Africans into the 'New World' in the $16^{\text {th }}$ century was but a trickle, when compared with its volume during the $17^{\text {th }}$, and with its culmination in the $18^{\text {th }}$ century. Still, many features of the later period were established already in the very beginnings. The $17^{\text {th }}$-century expansion of the slave trade was essentially triggered by the Sugar Revolution: the development of large scale sugar cane cultivation and sugar processing in the Caribbean, and subsequent rise in the demand for labour. Yet, the sugar business had been a motor of the expansion from its very beginnings, with entrepreneurs and capital from Central Europe being involved all the time. The Ravensburg linen trading company had invested in sugar production near Valencia on the Spanish Mediterranean coast, from the 1420s into the 1470 s, running its own plantation and a sugar mill. The Ravensburg merchants gave it up when far larger quantities of sugar started to pour in at a more competitive price from the Canary Islands and from Madeira (Phillips Jr., 2004: 33-34). In 1508, the Welser acquired one of the largest sugar estates on Tenerife, and in the following year they invested into more plantations and mills on the island of La Palma — only to give it all up in the 1520s, when the first Spanish settlement on Hispaniola offered even better prospects for cultivation of the cane (Vieira, 2004: 47, 67, 69; Stols, 2004: 261). In 1526 the Welser company opened a branch there, and from c. 1530 it was a shareholder of sugar estates on the island. In 1528, the very same company purchased the Asiento for providing the Spanish Caribbean with 4,000 African slaves. Portuguese merchants were contracted to carry out the actual shipping. In the very same year, the first ship under this Asiento crossed the Atlantic (Denzer, 2005: 51-55).

The Fugger dynasty had risen from a modest family of rural linen weavers to eminent Augsburg patricians, processing linen and cotton, and leasing mines all over Central Europe (Häberlein, 2006: 17). As financiers, they supported the election of the (since 1516) Spanish king Charles I as Emperor Charles V (1519) (Häberlein, 2008: 65-81). Their trading house had representatives in Lisbon from 1504 and in Seville from the 1520s, and it channelled 
huge quantities of copper from their own Alpine and Hungarian mines into the Portuguese slave trade. Already during the 1970s, the Polish historian Marian Małowist has hinted at this lucrative business - and to Central European involvement in general (Małowist, 1976). He investigated the bulk exports of metal ware from the Holy Roman Empire to Iberian ports via Antwerp and Bruges. This trade is well documented from the $1490 \mathrm{~s}$, but must already have been in place for decades. Chief items were "bangles, necklaces, cauldrons, basins and other produce made of copper, brass and iron", including chains to fetter the slaves. The bookkeeping of Portuguese middlemen in Flanders mentions tens and hundred thousands of such items coming from Nuremberg (Małowist, 2009c: 389). In his more recent monograph on the Fugger dynasty, Mark Häberlein provides evidence for the continuation of this trade from Nuremberg to Africa, reaching far into the $16^{\text {th }}$ century. In a contract signed with the Portuguese crown in 1548, the Fugger agreed "to purvey 7,500 hundredweights of brass bangles, 24,000 saucepans, 1,800 wide bowls, 4,500 barber's basins, and 10,500 cauldrons. All this brassware, to be delivered within a time-span of four years, was explicitly meant for the Guinea trade" (Häberlein, 2008: 80).

The Fugger, Welser, Höchstetter and more of the major entrepreneurs in Central Europe were industrialists, merchants and financiers at the same time, and they had made Augsburg the Holy Roman Empire's centre of banking and finance. Their westward routes of trading and communication, initially directed from Upper Germany across the Alps into the Mediterranean, were gradually shifting to a route directed via Flanders to Lisbon and further west. When the Portuguese began to develop sugar cane cultivation on a large scale in Brazil, the Fugger were still involved with agents present in the colony. By 1540 the Schetz family, originating from Aix-la-Chapelle but also established in Antwerp, had acquired large Brazil sugar estates. Previously, they had been importing sugar from São Tomé. This family indicates the increasing presence of merchants from the Netherlands and the Lower Rhineland in the Iberian Atlantic economy (Stols, 2001: 29-47; Stols, 2004: 262-263). Such changes already hint at the $17^{\text {th }}$-century decline of Upper Germany's economy, and to the economic rise of areas further north in the Empire. This shift was essentially favoured by the steady development of the Atlantic economy, but accelerated by the Thirty Years War, which dealt a blow to most Catholic powers.

During the first phase of this war, the Dutch had conquered the richest sugar-producing regions in Brazil, and in order to supply them with labour, they established their own slave trading posts on the West African coast. This period also saw the creation of large joint stock trading companies. The Dutch East India Company (VOC, founded in 1603) and Dutch West India Company (WIC, operative from 1623) offered new opportunities for investment. The Augsburg entrepreneur and banker Marx Konrad von Relingen acquired shares in both companies worth 50,000 fl., and he invested another 110,000 fl. in British shipping ventures, much of it directly related with the African trade. In 1621, Johann Friedrich Duke of Württemberg spent 30,000 fl. in the Dutch WIC, thus figuring among the company's very first shareholders. Yet, not only was capital flowing out of the country, it was also coming in, much of it contributing to the rise of Frankfurt on the River Main. Johann von Bodeck (15541631), then considered the wealthiest man in town, had arrived from Antwerp as a Protestant refugee, transferring his business to Germany. He made his fortune in the copper trade and in loans to German territorial rulers, which in fact makes him a successor of the great houses of the Fugger and Welser (Schilling, 1983: 22-23). Imperial bureaucrats claimed that von Bodeck had invested "several tons of gold" in the Dutch maritime companies.

He was among those who made Frankfurt the successor of the Empire's previously leading financial cities of Nuremberg and Augsburg, which were in sharp decline by 1620 . Augsburg, a wealthy city with 48,000 inhabitants in 1600 , counted but 21,000 when the Thirty Years War had ended. It was to recover slowly only during the $18^{\text {th }}$ century. The size of Nuremberg's population slumped from 40,000 in 1600 to 30,000 in 1700, in Ulm it dropped from 21,000 to 15,000 . The larger Hanseatic port cities, in contrast, were expanding significantly during the period from 1600 to 1650: Hamburg grew from 40,000 inhabitants to 75,000 , Lubeck from 23,000 to 31,000 inhabitants (de Vries, 1984: 272-273).

It is true that the rural linen industry of Swabia and the whole region surrounding Lake Constance remained very important and even expanded during the $18^{\text {th }}$ century, but only a small fraction of its exports continued to be dispatched on the traditional transalpine routes. Swabian linen and even much of the Swiss fabrics were now sent north, to be exported via the Austrian Netherlands or via Bremen and Hamburg. This change must be seen in the context of the expanding trans-Atlantic slave trade. The sugar revolution in the British Caribbean, the expansion of sugar production in Brazil, and the spectacular rise of sugar plantations on early $18^{\text {th }}$-century Saint-Domingue caused a multiplication in the volume of the slave trade, and its shift from the Iberian into the Dutch, British and French Atlantic. During the entire $16^{\text {th }}$ century, Europeans had deported almost 0.3 million Africans into the 'New World'. In the 25 years before 1700 , their number was more than 0.7 million, but in the 25 years before 1750 , it came near to 1.5 million men, women and children (Eltis and Richardson, 2008). The African demand for barter goods, generated by the trade, and its impact on Central European economies cannot be underestimated. This demand was one of the reasons for the growing European import of cotton fabrics from India (much of it to be reexported to Africa and bartered against slaves), and at the same time it contributed to the expansion of linen production in Central Europe. Most of the expansion was achieved in more northern regions of the Holy Roman Empire: in Westphalia, Hessen, Pomerania, Lusatia and Silesia. Even though some of these provinces seem to be quite landlocked, they were in fact provided with very efficient navigable waterways to the North Sea and the Baltic Sea. 


\section{THE SHIFT TO THE NORTH SEA AND ADAPTIONS TO $18^{\mathrm{TH}}-$ CENTURY MARITIME TRADE}

Silesia and Bohemia had already been integrated into the European textile economy during the $16^{\text {th }}$ century, when the Fugger and Nuremburg textile magnates transferred much of their rural linen production from Swabia and Franconia further east, capitalising on the lower wages to be paid there (Aubin and Kunze, 1940; Kunze 1925). Both Silesia and Bohemia were heavily devastated during the Thirty Years War, but had fully recovered by 1700 .

A Prussian achievement in civil engineering and a Prussian military adventure illustrate the economic importance of Silesia and its reliance on long-distance trade: The Prince-Elector Friedrich Wilhelm initiated the construction of a canal which linked the River Oder (flowing from Silesia into the Baltic Sea) with the River Spree (feeding the Havel, which in turn feeds the River Elbe), thus completing a navigable waterway of c. 760 kilometres, from Silesia's capital Breslau into the port of Hamburg. Merchants using this direct route to the North Sea avoided the Danish sound toll, but had to pay newly established Prussian duties. The 28 kilometres and 13 watergates of the canal were opened in 1668. From 1740 until 1763, Friedrich Wilhelm's great grandson Friedrich II (the Great) waged three costly wars for the conquest of Silesia, which had so far been a province of the Habsburg Empire. After the change of ruler, the linen magnates in Silesia's wealthy trading towns, such as Hirschberg (today Jelena Góra), Greiffenberg (today Gryfów Śląski) and Landeshut (today Kamienna Góra) readily adapted to Prussian rule and intensified their exports via Hamburg, while the older links with Upper Germany and Austria were neglected.

The Elbe River provided Bohemia with direct communication to the sea port of Hamburg. This Habsburg province produced not only linen, but also metal items and glassware. From the 1680 s, traders from the remotest Bohemian mountain villages travelled as far as London, Amsterdam and Cadiz to distribute their merchandise, notably crystal glass. New roads were built during the $18^{\text {th }}$ century to make sure a smooth transportation of fragile commodities from the glassworks to the riverboats on the Elbe (Myška, 1996: 188-207; Weber, 2004: 75-79, 133-143).

The old-established Westphalian linen trade had always been directed towards the ports of Amsterdam, Bremen and Hamburg, and towards British markets. They naturally benefited from the closer integration of the North Sea region into the Atlantic economy, in particular after the Thirty Years War. The merchants of larger Westphalian cities like Bielefeld, Osnabruck and Warendorf tightened their control of rural linen spinning and weaving, and established efficient institutions for quality control. Many of them had originally come from neighbouring villages of textile production (just as the Fugger had in their time). A steady migration to Hanseatic and Dutch ports and to London secured a significant urban presence of Westphalian merchants, and many of them actually made their way into the very elite of these cities. This strategy ensured a tight vertical integration of their family-based business (Beerbühl, 2007; Weber, 2004). The main transport route through Westphalia was the River Weser, with the Hanseatic city of Bremen on its estuary into the North Sea. The river's upper course also links Hessian linen regions with Bremen.

The orientation of Central Europe's rural industries towards the sea was corresponding to the growth in $18^{\text {th }}$ century's maritime trade. The slow but steady pacification of the Atlantic Ocean and of the Caribbean, and the suppression of piracy contributed to the reduction of transaction costs, which encouraged more individual traders to enter into the business, including the slave trade (Emmer, 1998: 12-32). German merchants too benefitted from these changes. A significant number of them did so by establishing themselves in a sea port of a slave trading nation, and they operated under the respective flag. A few such examples from London, Bordeaux, Nantes and Cadiz will illustrate how German merchants linked the Central European economy with Atlantic markets (Weber, 2009, 37-67).

\section{London}

Sir Peter Meyer from Hamburg came to London in 1690 and figured among the first Anglo-German slave traders and slave owners. He acquired a plantation on Barbados and shares in a London sugar refinery, and was knighted in 1714. According to a register of the Knights of England, he even became a director of the Royal African Company (Beerbühl, 2007: 111-112). Abram Korten, from the linen processing city of Elberfeld (today Wuppertal) had become a shareholder of the South Sea Company by 1740 . The company had been created specifically for the Asiento trade in slaves to Spanish America. He was a sugar importer and a business partner of the English banking brothers Alexander and David Barclay, who were still active in the slave trade at that time, but turned abolitionists later. Like Peter Meyer and a few more Germans in London, Korten also became a member of the East India Company, a major provider of calicoes for Africa (Beerbühl, 2007: 342-344). The presence of many larger and smaller entrepreneurs in Elberfeld demonstrates the general importance of this place for export trade (Overkamp, 2014).

The brothers John and Francis Baring, textile merchants from Bremen, arrived in London around 1720. By 1750 they figured among the members of the Company of Merchants Trading to Africa (Gary, 1935: 506), and within a few decades they had made their way into the ranks of the city's leading merchant bankers. Well into the $19^{\text {th }}$ century, financiers and Members of Parliament from the Baring family continued to be influential pro-slavery lobbyists. At least until 1850, the Barings were among the major exporters of sugar from Cuba, where slavery was abolished only in 1886 (Williams, 1994: 171). Their prestigious house went bankrupt only in 1995, due to a rogue trader's unauthorised speculation in derivatives. 
Another major London merchant bank of German origin was established by Bernhard Heinrich Schröder, who arrived in London well before 1800, and Johann Friedrich Schröder (1780-1852), a relative from the following generation. It is operating today as an asset management company. The family originated from Quakenbrück, a small town in the Bishopric of Osnabruck, but it was also present in Bremen and Hamburg. Johann Friedrich's brother Johann Heinrich (1784-1883, better known as John Henry Schroder) commuted between London and Hamburg, where he created a sugar refinery in 1819 . In the Hanseatic city, he is also remembered as an eminent philanthropist. A third brother ran a refinery in Saint Petersburg. By 1850, the London bank had 53 Cuban clients on its books, and John Henry's trading house in Liverpool ranged among the major buyers of cotton from the US South. J. H. Schroder \& Co was the only major London bank which issued bonds for financing the war effort of the Confederate States (Roberts, 1992: 28-35, 41, 53-54, 65-67).

\section{Bordeaux and Nantes}

France was a late-comer among those European nations who developed colonies in the New World. On Saint-Domingue, large-scale plantation economy was developed only from the 1710 s and 20 s, but this was done with such efficiency that within a few decades, the island became the world's largest producer of raw sugar. France subsequently became the biggest provider of sugar to Central Europe, and one of the major slave trading nations. This explains why Germans were of little importance in French Atlantic sea ports before 1700. Their increasing presence and importance during the $18^{\text {th }}$ century demonstrates that they always adapted swiftly to the most recent development in the Atlantic world.

One of the first among the German-born entrepreneurs settling in Bordeaux was Johann Christoph Harmensen. He arrived there in 1708, married a woman from the local bourgeoisie, and he was successful enough to soon acquire a major plantation on Saint-Domingue. In 1743, his 23 year old son Michel went there, to manage the estate for a couple of years. Johann Christoph Harmensen and his sons also engaged in the trade of colonial produce and of French wine to Hamburg and Bremen, and in the importation of grain, and of timber, tar and other naval supplies from Baltic seaports. They also supplied Saxony's textile manufactures with raw material, which won them a noble title from the Prince of this industrious land (Weber, 2004: 208-210).

Friedrich Romberg, born 1726 in the iron- and textilemanufacturing town of Iserlohn, not far from Elberfeld, started his career with a haulage company which linked the Austrian Netherlands with Italy. During the American War of Independence, he capitalised on the neutral flag of the Austrian Netherlands. Jointly with his sons, he created a company based in Ghent for trading slaves to SaintDomingue and Cuba, a maritime insurance company in Bruges, and a calico production in Brussels. At the out- skirts of his hometown Iserlohn, he established an important linen bleaching plant. He also became a financier, with excellent contacts to the mint in Brussels, and to the Imperial Court in Vienna. In 1784, he created jointly with the Brussels banker brothers Walckiers and his senior clerk Georg Christoph Bapst the slaving company Romberg, Bapst \& Cie. It was based in Bordeaux and was to become the city's largest slave trading company, with up to six ships in service and 200 sailors on its books at the same time. By 1789, the company had also become manager of 20 plantations on Saint-Domingue. Some of them became its own property, due to the widespread over-indebtedness of the planters towards the slave traders. When the firm went bankrupt, during the Haitian Revolution, efforts were made Europe-wide to save it, but without avail. The accounts were finally settled in 1807, with total losses amounting to more than 34 million Livres tournois (Thésée, 1972; Weber, 2004: 195-204). The astronomic sum caused financial turmoil in Europe's major banking cities, among them Frankfurt on the Main.

One of the supporters of Romberg's seesaw Bordeaux firm had been Frankfurt's leading financial house Bethmann Brothers. The wide diversity of their business helped them to compensate for the losses they made with Romberg. The merchant bankers Johann Philipp Bethmann and Simon Moritz Bethmann were involved with the copper trade and the trade in colonial produce, which was facilitated by a third brother, established in Bordeaux since 1740. Johann Jakob Bethmann (1717-1792) had made himself one of the city's major shipping magnates, active in the trade with the French Caribbean and with Canada (Henninger, 1993; Weber, 2004: 190-195). He was not involved with the slave trade, but with the redistribution of French Caribbean produce from the Gironde estuary to Central European markets. In the second half of the $18^{\text {th }}$ century, at least a dozen merchants and merchant bankers from Frankfurt were established in Bordeaux, among them members of the Metzler family. In Frankfurt, their banking house ranked second, next to Bethmann Brothers. Jean Albert Metzler (1742-1767) lived on Guadeloupe and Martinique. His younger brother Peter (1748-1823) worked as a merchant on SaintDomingue well into the 1780s (Henninger, 1993: 572$573,614)$.

While Nantes was the major French slaving port, $18^{\text {th }}$ century Bordeaux was the country's most important emporium for receiving and reshipping the produce from the Antilles, such as sugar, coffee, indigo and cotton. German trade with Bordeaux was crucial for the French colonial economy. The city's by far major trading partner was Hamburg, Germany's major seaport. In 1788, Hamburg's imports from Bordeaux corresponded with the threefold value received from all English ports combined. ${ }^{1}$ About 30 out of the 411 slave ships sailing from the Gironde during the $18^{\text {th }}$ century were owned by Germans and Swiss Germans settled in Bordeaux (Romberg, Bapst \& Cie were owners in at least 14 expeditions) (Saugera, 1995). Further foreign participation through minor shares in French-owned ships remains invisible, but was also 
considerable. The financial impact from Central Europe was even stronger in Nantes. At the eve of the French Revolution, about one third of the shares of the Compagnie des Indes Orientales, operating from Lorient and from Nantes, were held by Swiss investors (David and Etemad and Schaufelbuehl, 2005: 25). This presence of agents and capital from German and Swiss financial centres needs to be understood in the context of the enormous demand for capital generated by the plantation economy and the slave trade, and of the profits to be expected. The major protagonists were awarded honours and noble titles. In 1763 the above-mentioned Johann Christoph von Harmensen was ennobled by August III, Prince Elector of Saxony and King of Poland. Both Johann Jakob von Bethmann and Friedrich von Romberg were knighted by the Emperor of the Holy Roman Empire, in 1776 and 1784 respectively. At least seven of the German families established in Bordeaux received such hereditary titles, usually acknowledged by the French crown.

\section{Cadiz}

During the $18^{\text {th }}$ century, Spain was still a minor player in the slave trade. This explains why the country was relying on the Asiento trade for supplying its American colonies with unfree labourers. In 1765, the Compañía gaditana de negros was established, as part of the effort to expand Spain's own slave trade (Torres Ramírez, 1973). Its weak position in this sector is illustrated by the fact that the major shareholders of the Compañía gaditana came from France: Armand and Prudencio Delaville. Their brother François Delaville and their brother in law François Deguer ran the company Delaville \& Cie, one of the major slaving enterprises in Nantes. Like slave traders in Britain or France, the Compañía gaditana was keen for supplies of Central European fabrics. This was secured by a familial alliance of the Delaville with a German-speaking family from Alsace, already a French province during the $18^{\text {th }}$ century. In 1776, Prudencio Delaville married Francisca María Quintanilla-Schlieper. She was the daughter of Johann Jakob Schlieper from Benfeld, near the Alsatian capital Strasbourg, and of Ines Quintanilla from Puerto Real. Alsace and Northern Switzerland constituted one large region of cotton processing and calico production, extending from Neuchâtel through Bâle and Mulhouse to Strasbourg. Much of its produce was exported via Ostend into the Atlantic world (Pétré-Grenouilleau, 1996: 58; Veyrassat, 1928: 118). Johann Jakob Schlieper was established in Cadiz, as an associate of merchants from the Ellermann family. Three Ellermann brothers had come to Spain around 1720 from a village at the outskirts of Osnabruck in Westphalia - the above-mentioned famous linen region. Around 1730 Hermann Ellermann was even travelling in the Spanish American colonies, which can only have been illegal, given the family's Protestant faith. The Ellermanns were also present as merchants and ship owners in Hamburg and as merchants in Amsterdam. Their Cadiz branch Ellermann Schlieper \& Cia thus merged contacts between a Northern German linen region and a Swiss-German calico region with the most crucial German and Dutch seaports. According to taxation registers, it was the most successful German trading house in $18^{\text {th }}$-century Cadiz, and overall one of the city's most successful houses. For her marriage with the slave trader Prudencio Delaville, Francisca María QuintanillaSchlieper was provided with a dowry worth 65,559 pesos, an extraordinary sum even among the very wealthy elite of the French traders in Cadiz. When Prudencio had to declare his fortune in 1793, in the context of his attempts at naturalisation, he was assessed the wealthiest man in this wealthy city (Weber, 2004: 123-130, 273-275; Weber, 2010: 101-122).

Among the almost 250 German merchants whose presence in Cadiz has been established for the period 1680-1830, Schlieper and Ellermann provide the most prominent example. The total number of Germans in Cadiz, the total of c. 225 Germans in Bordeaux during the same period, and of c. 335 in London from 1715 to 1800 (Beerbühl, 2007; Beerbühl, 2010: 101-121), demonstrates that merchants and merchandise from Central Europe were an important factor in Atlantic trade. Most of those Germans had not come from the Hanseatic cities, but directly from those particular rural regions where the protoindustrial production of export commodities was flourishing. These trades had succeeded in establishing a remarkable vertical integration of the commodity chain, from the processing of the raw materials to the distribution to the consumers.

\section{QUANTITATIVE IMPACT}

To what extent did this presence of a German commercial elite in major port cities of colonial empires have any tangible impact on the Central European hinterlands? This question can only be answered by a quantitative assessment of the exportation of Central European products and the influx of colonial goods on Central European markets.

The taste of consumers in colonial markets is reflected by an 1806 report of British merchants to Parliament: "The Spanish Traders are very strongly prejudiced in favour of German linens... When a Spanish trader comes into a store in a British [Caribbean] Island, the first article he asks for is German linens..." (Krawehl, 1977: 441). Another report, dated 1744, reported that the 70,000 slaves on Barbados were "usually clothed with Foreign "Osnabrughs"' (British Parliamentary Papers, 1975: 1819). Such labelling demonstrates that the products from particular Northern German regions had made themselves a name, as 'stout Weser flaxen', 'true born Osnabrughs', 'true born Tecklenburghs' (Tecklenburg is a county in the province of Westphalia), or 'Creguelas de Westphalia' and 'Rosas de Westphalia' (Schmitz, 1967: 33, 86, 92).

These fabrics were not only in demand in American colonies, but also in Africa, where the portion of German manufactures among the barter commodities used for the purchase of African slaves was significant (Klein, 1999: 114). Even the assortments on board of early Portuguese 
slave ships were made up entirely with merchandise produced outside Portugal, mostly from more Central and Eastern European regions (Ryder, 1959: 294-321). Bills of lading preserved from the 1660s show that hardly any East India ship would set sail from Britain for Africa without a substantial quantity of Silesian linen in its holds, labelled 'sletias' (Makepeace, 1989: 239, 255268). The slave ship Amiral, which left Bordeaux for the Guinea coast in 1744, had the bulk of its cargo made up with textiles, as most slavers would. Out of the total of 5,095 bales of cotton and linen on board, 1,440 derived from Nantes, far smaller batches from Rouen and Amsterdam, but as much as 2,720 from Hamburg (Saugera, 1995: 246, 352).

The British ship Mermaid offers a similar picture: In 1732 , before setting off for the Guinea coats, its captain had purchased textiles in Rotterdam, with a total value of 23,335 £. Half of them were composed of Silesian linen (Kobayashi, 2010). Much of the remainder, labelled 'bretannies' and 'cambrics', may also have been of German origin (Kobayashi, 2010). Counterfeits of the traditional linen from Cambrai and French Brittany were made in Germany, and much of it was distributed via Dutch harbours.

Such rather punctual observations on overseas markets are confirmed by broader data from German regions of textile production. In his examination of the Prussian customs registers, Alfred Zimmermann emphasises the significantly Atlantic bias of the exports from the landlocked province of Silesia. From the 1740 s to the 1780 s, more than three quarters of its linen produce - the annual value was oscillating roughly between three and six million Taler- was destined for the markets of Western European sea powers. Some of it was even shipped directly to the Americas, but only a tiny fraction of the exports was sent east (Russia, Poland, Hungary, Ottoman regions) (Zimmermann, 1885: 460-467). Far smaller German territories also exported large quantities. In the late 1780s, the annual linen exports of the County of Ravensberg (in Westphalia; not to be confused with the above-mentioned Ravensburg, near Lake Constance) were worth some 0.75 million Taler (Schmitz, 1967: 81). Similarly structured export markets have been observed in the case of metal ware from the Rhineland (Reininghaus, 1995: 585).

The British example demonstrates the importance of German textiles on Atlantic markets: In the first half of the $18^{\text {th }}$ century about 15 per cent of all imports to Britain consisted of linen. As Karin Newman has pointed out, 70 to 80 per cent of all imported linen textiles came from Germany, and 90 per cent of this volume was re-exported across the Atlantic. This implies that around 1700, about two-thirds of all British linen exports were of German origin. Irish linen followed in second place, and English textiles only ranked third (Newman, 1979: 202). This also illustrates to what extend the already mentioned book on The European Linen Industry is missing the wider picture (Collins and Ollerenshaw, 2003). If all the bales of German-made linen channelled through Britain in any one of these years had been unrolled and pieced together, it would have produced a length of 11,000 kilometres large enough to span the Atlantic from Britain to New England, and on to Jamaica.

The French and Spanish contexts provide similar examples. The accounts of the important French trading house of Fornier frères, established in Cadiz, reveal that about two-thirds of its textile purchases during the years from 1768 to 1786 were made in Germany. Out of the total expenditure of 12 million Reales, roughly 3 million were spent in Hamburg, 1 million in Bremen and 2 million in Silesia. Something between 1.5 and 2 million Reales was spent in Holland, probably also for German fabrics, as Dutch ports served as important outlets for Westphalian goods. Only some 35 per cent of the purchases of these French traders were made in France (Chamboredon, 1991: 35, 49). At the same time, the Spanish textile industry too absorbed important quantities from Central Europe. According to Pierre Vilar, the Catalan industries imported in the year of 1793 only some 1.2 million ells of linen (equivalent of almost 1.1 million metres) from Hamburg. They were usually printed or dyed in Catalonia before being re-exported as Spanish fabrics (Vilar, 1962: 118, 126).

The huge volume of rural textile production for export markets also had an impact on population growth and social structure in Central Europe. German labour-intensive proto-industries typically emerged in regions where poor soil and climate obliged the rural population to earn additional income, to purchase food supplementing their local harvests. The poor wages which cottagers (including women and children) would accept attracted textile producers to transfer manufacturing to such provinces. The general tendency was a move from more western and more urban to more eastern and rural areas - it can already be observed with the dislocation of some of the Fugger textile production into Bohemia and Silesia. With ever increasing volumes of German manufactures being exported, such hitherto poor regions became permanent importers of food, allowing for an escape from the Malthusian trap.

In the course of the $18^{\text {th }}$ century, rural families even developed a taste for previously inaccessible goods like sugar, coffee, tobacco and chocolate, and for a more decorative clothing which also relied on colonial produce such as cotton, indigo and cochineal. In fact, besides in the cities, it was proto-industrial regions where Central European consumption of colonial produce first took off. Tenant farmers who once could hardly survive on their small plot of land began wearing attires which sumptuary laws actually had assigned for the upper social strata. Complaints on this were multiplying, such as:

There are many examples of girls who parade around their entire earnings by hanging fineries to their bodies; and of young men $[\ldots]$ who spend their savings on a silver watch, silver buckles, a Meerschaum pipe with silver decorations, $[\ldots]$ and who use up the rest of their earnings on beer and brandy (As cited by Kriedte, Medick and Schlumbohm, 1982: 69). 
Peter Kriedte, Hans Medick and Jürgen Schlumbohm have accurately described this as a new "plebeian culture". Women and children earned a cash income, and when the proto-industrial labour division within the household required men do so, they would also take on the traditionally female tasks of cooking or spinning. Boys and girls would no longer assist their parents as field hands, because with their dexterity they were more profitably employed preparing raw hemp, flax and cotton, and for spinning and weaving it (Sandgruber, 1983: 135149; Radeff, 1996). Such descriptions are substantiated with quantitative data from key trading places. The tax revenue levied on coffee in the towns of Lusatia increased fourfold from 1750 to 1780 , the revenue on coffee at the Leipzig fair increased by $33 \%$ from 1775 to 1781, the revenue on cotton more than doubled during the same period. Similar growth rates have been observed for the 1769-1772 trade of sugar, coffee and tobacco in Magdeburg, Prussia's major city on the River Elbe (Zeuske and Ludwig, 1995: 290, 277).

The general increase of purchasing power did above all allow for a more secure provisioning with staple food. It is true that sharp increases in food prices could cause famines well into the $1840 \mathrm{~s}$, but the overall nutrition was improving already during the $18^{\text {th }}$ century (Komlos, 1989). In consequence, most of the demographic growth in $18^{\text {th }}$ century Germany was generated in proto-industrial rural areas, and in particular among the landless poor who depended even more on income in cash. In the Westphalian linen regions of Bielefeld and Osnabruck, population density increased from 42 inhabitants per square kilometre in 1722 to 74 inhabitants in 1801. Around that year, the German average per square kilometre was around 40 to 45 inhabitants (Wischermann, 1992: 87). Similar figures from proto-industrial regions in Silesia (linen), Pomerania (linen), Swabia (linen, clocks) and Bohemia (linen, metal ware, glassware) indicate how widespread this phenomenon was (Göttmann, 1991: 2-11; Salz, 1913: 283). In some areas, the population growth between 1750 and 1800 even exceeded 100 per cent. Hans-Ulrich Wehler reckoned that the causes of this 'Demographic Revolution' are still unknown, but that the proto-industrial development might provide some approach to the problem (Wehler, 1987: 6970). He failed to provide empirical evidence, but it seems very much that his assumption hits the nail on the head.

\section{GEOGRAPHY AND COMMERCE}

Which factors forwarded such a close integration of German lands, with a continuity which was unhampered by all the significant changes the Atlantic economy experienced from the $15^{\text {th }}$ to the $19^{\text {th }}$ century? This question can only be answered by looking at the commodities which Central Europe produced for Atlantic markets. The dominating manufacture was textiles, mostly linen, and far smaller shares of calicoes, fustians and silk (Kisch, 1968). Metal ware ranked second: ironmongery, tin sheets, arms and armour, anchors etc. These were complemented with copper sheets, lead, all sorts of wires, and the above men- tioned wide range of brassware. Next to textiles and metal ware came glassware, mostly from Bohemia. This basic assortment was complemented with smaller batches of wax, musical instruments, clocks, haberdashery, and other labour intensive products. Alongside those manufactures, German harbours exported grain (mostly from hinterlands of the Baltic Sea), and timber. Much of the timber had already been processed: beams and bulkheads, masts and planks were sent to shipyards all over Western and Southern Europe; staves were in demand at shipyards and in wine-growing regions all over. Cordage, heavy canvasses, hemp and tar completed the range of naval stores (Zorn, 1961: 421-447; Kellenbenz, 1964: 4-60; Weber, 1999: 93126).

Some of the products stand out by labour intensity: textiles, ironmongery, glassware, clocks and instruments. Some of those, on top of that, by extreme energy intensity: glassware, and all metal products. This hints at labour and energy as location factors which attracted relevant industries into Central Europe. The Holy Roman Empire had in fact been Europe's foremost producer of metals and metal products. The total of Europe's iron production in the early $16^{\text {th }}$-century was at probably 60,000 tons p.a., and half of it was smelted in the Empire: in Saxony, Southern Westphalia, Styria, Tyrol, the Black Forest and many smaller places. Copper was mined and processed on the southern slopes of the Harz Mountains, tin in Saxony. Only during the second half of the $18^{\text {th }}$ century, when coal mining and the coking technique had put an end to energy shortage in Britain, did the British steel industry begin to outperform German competitors, at least in some of their sectors (Reininghausen, 2008). Steel making in Sweden and Russia and in some German regions continued to rely on charcoal well into the $19^{\text {th }}$ century - due to abundant forests.

This abundance of rather renewable energy also benefitted glassmaking. After the Thirty Years War, during the period of general recovery, Bohemia became Europe's major producer of glassware. Quite some of this was due to successful industrial spying upon the Venice glass industry. French manufactures were technically more advanced in some branches of the industry, but had higher energy costs. Lack of fuel was even more pressing in Spain. The 'Real Fábrica de Cristales de San Ildefonso' provides an example; it never became a profitable enterprise (de Viñas, 1994: 466, 486-489). Only when coal mining and cheap railway transport of coal allowed for the creation of glass industries outside the densely wooded mountain ridges of Central Europe did Bohemian glassmaking come into crisis.

The supply with timber and firewood (and with flax) relied on moderate, but dependable rain. Central Europe was well-provided with this resource, which allowed for a sustainable use of the vast forests. Deforestation in Central Europe had never become as devastating as in the Mediterranean world and on the British Isles and Ireland. Reliable precipitation not only made the trees grow. It also secured provision with hydraulic energy. On hundreds of larger and smaller streams and rivers, watermills 
were driving headgears and pumps of mines, bellows and hammers of steel mills, sawmills, and other early modern machinery. Mountainous landscape made sure that downward slopes provided sufficient drive.

The hydro-geography of the continent shows yet another feature, which was essential for transportation routes: The major cordilleras of Central Europe are all stretching along an east-western axis: Alps, Erzgebirge (the 'Ore Mountains' on the Saxon-Bohemian border), and Carpathians. Further, these mountain ridges are situated in the continent's rather southern regions, with vast plains stretching from there northwards to the coasts of the North Sea and of the Baltic Sea. All rainfall between the watershed on the ridges and the coast is feeding large rivers, all flowing north, and being mostly navigable: Rhine, Weser, Elbe, Oder, Vistula, Memel. There are longer and more powerful rivers, like Mississippi and Amazonas, or Niger and Congo, but they do not cover the respective continents in the same evenly way, and therefore do not provide the same opportunities for transport. In France, where no cordillera sends all waters either to the Atlantic or to the Mediterranean, few rivers are navigable. Spain, in turn, is crisscrossed with mountain ridges, which did neither allow for the formation of a system of naturally navigable waterways - while the geography of Central Europe provided even the deep hinterlands with river routes facilitating the transportation of commodities to the coasts. This enabled already the medieval Hanseatic and Dutch merchants to integrate the North Sea and the Baltic regions into one 'économie monde', speaking in Braudel's terms.

But even the most favourable geographic conditions alone will not motivate commerce and trade. These will only thrive if raw material, labour, products or services available in one region are lacking in another, or if they are more expensive there. A driving factor for all the mercantile activities here described has been the decline of wages (measured in silver or gold) from areas which are well-provided with precious metals (e.g. West Africa and Spanish America) to areas which are more poorly provided (Eastern Europe, Asia). The more poorly provided regions always tend to attract labour-intensive trades, for which textile production is the ideal example (even today). Profits from this trade can be maximised if the product is sold were the highest prices (measured in silver or gold) may be obtained, which was rather in the Western hemisphere. This explains the long continuity of textile production in Central Europe, and of westward exportation. It also explains the early integration of Upper Germany into the 'économie monde' of the medieval Mediterranean world. Gold from Africa and relatively low wages north of the Alps made even transalpine trade a lucrative business. With the expansion into the Atlantic, this European 'économie monde', which had already integrated the North Sea and the Baltic regions, also swallowed up West Africa and the Americas. From the Spanish conquest of Mexico and Peru did American silver increase the attractiveness of Central Europe as a location for labour intensive industry.
While economic and military power slowly shifted from the Iberian into the more northern Dutch and British Atlantic, the strongholds of Europe's Atlantic trade were moving clock-wise along the continent's maritime fringes: from Venice and Genoa to the Spanish Mediterranean coast (Valencia) and Lisbon. When the Netherlands, in fierce competition with the Iberian powers, claimed its own share in Atlantic shipping and trade, the strongholds moved on to Holland and London. Accordingly, the rich and powerful Imperial Cities in the South of the Holy Roman Empire - Ulm, Augsburg, Nuremberg, etc.- - lost quite some of their economic weight. They were superseded by Frankfurt on the Main and by the Hanseatic Cities. The bulk of manufactures made in territories of the Holy Roman Empire was not channelled through Genoa anymore, but rather through Dutch harbours, and through the Hanseatic ports of Bremen and Hamburg.

Following the more recent assumptions that space does not exist as such, but that it is always a social construction, it may be concluded that the space in which Central European economy existed, and the world surrounding it, were largely created by the commercial activities which interlinked them. These links were surprisingly dense, and contemporaries were very much aware of it. In a letter he wrote to his diplomat August von der Goltz in 1779, Frederick II claimed that the Silesian linen trade was the "Peru" of his kingdom (Zeuske and Ludwig, 1995: 274). In 1787, the German economist C. L. P. Hülpeden stated that the Hessian linen trade was the "Hessian Peru and West India", the "major canal through which gold and silver is flowing into our coffers" (as cited by Kriedte and Medick and Schlumbohm, 1981: 86). Manfred Kossok claims that at that time, the peso from Mexican and Peruvian mints was so much in use in Silesia that it was even considered to make it an official currency of this province (Kossok, 2000 [originally published 1961]: 214). Spain was placed right between the far ends of the space here described: Spanish America in the west, and the Holy Roman Empire in the East. The effects of the early modern Price Revolution the inflationary process coming with the American silverwere devastating for labour intensive trades in Spain, and they favoured such sectors in regions further east. No wonder then that Policarpo Saenz de Tejada Hermoso, one of the major merchants and bankers in late $18^{\text {th }}$-century Madrid, was complaining that the country was covering its demand in textiles mostly from Germany, and that even the children were playing with toys made in Germany, while the formerly important textile manufactures of Segovia had been left with but one single client: the King (Zylberberg, 1993: 65-66).

\section{RESEARCH PERSPECTIVES AND SCHOLARLY PAST}

During the $19^{\text {th }}$ and $20^{\text {th }}$ centuries, many German historians, geographers and economists were not at all enthusiastic with Germany's political, economic and even geographic conditions. Historicists like Johann Gustav Droysen (1808-1884) and Heinrich von Treitschke (1834- 
1896) were desperate for political unification (under Prussian rather than Austrian hegemony), economists from Friedrich List (1789-1846) to Gustav Schmoller (1838-1917) complained that political fragmentation crippled all prospects for German industries.

Schmoller and List complained that customs barriers between the multitude of small German states and territories, different systems of taxation and administration worked to the disadvantage of German trade and were rather one of the causes for the omnipresence of British industrial products on domestic markets. Yet, such claims have long been dismissed. Statistics on British-German trade of the years from 1827 to 1833 even reveal a balance in favour of German exports to Britain (Kutz, 1974: 4, 1215 ), and the presence of commodities made in Germany in the western hemisphere has been demonstrated above. More recently, Oliver Volckart has provided an explanation (Volckart, 1999) from the perspective of New Institutional Economics. Under this approach, not only private actors (individual merchants, trading companies etc.) are considered as actors on markets, but also institutions. States, ranging among the most powerful actors, are thus regarded as competitors for a variety of resources. The more actors there are, the more lively the competition. One of the resources sought by states is investors in industry and trade. They can be attracted by low taxation and low tariffs. Volckart thus compared the economic attractiveness of a number of German territories by institutional location factors, which in turn were shaped by the respective policy. He came to the conclusion that export economy was thriving rather in those German regions where a

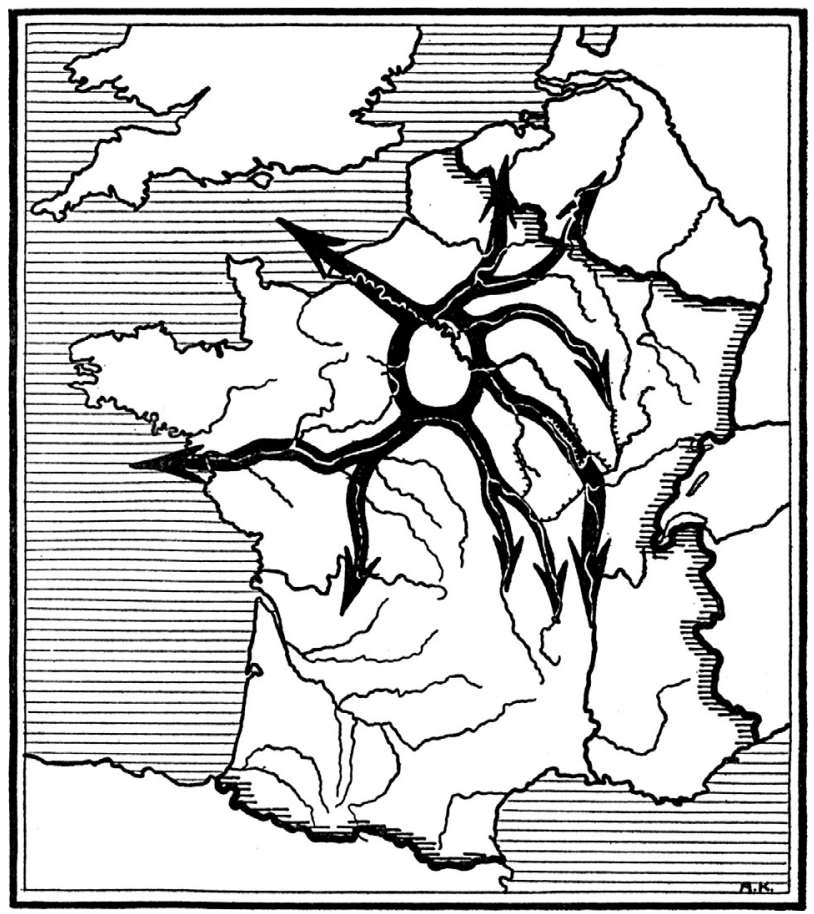

FIGURE 1: France: Rivers favouring centralized government from Paris (Obst, 1928, p. 29) larger number of smaller territories was competing (e.g. in the Rhineland), while the per-capita export rate of the larger states (Prussia, Bavaria ...) was significantly lower than in more western territories. It is true that some of the Rhenish counties (Mark, Tecklenburg, Cleve) did belong to Prussia, but they were situated outside the customs boundaries of Prussian core lands and thus rather neglected by Prussian economic policy - which came to their advantage. Alsace, with its cotton mills emerging in the $18^{\text {th }}$ century, provides another example where regionalism on the periphery of increasingly centralised monarchies worked in favour of local industry. The German-speaking province had been annexed by France under Louis XIV. Bohemia and Silesia also benefitted from their situation on the fringes of the Habsburg Empire and of the Kingdom of Prussia respectively. The attempts of Frederic II to impose his mercantile policy on the Silesian linen trade remained futile (Nolte, 2004). This allowed local authorities to keep administration lean, taxes low, property rights reliable, and incentives high. It was Volckart's merit to provide a broader basis to this explanation, but the principle of such competition between larger and smaller states and territories had already been described by Max Barkhausen (Barkhausen, 1958; also see Kisch, 1959).

While $19^{\text {th }}$-century authors like Schmoller and Droysen wished to shape politics, the geographer Erich Obst (1886-1981) quarrelled with topography. Obst was a staunch follower of Hitler, and he was coeditor of Karl Haushofer's Zeitschrift für Geopolitik. According to an article he published there in 1928, the characteristic orientation of Central Europe's rivers towards the north was one of the causes for the lack of centralisation in Germany. In employing highly suggestive maps, he demonstrated the completely different pattern of navigable rivers in France and Russia - two of Germany's major political rivals (Obst, 1928, 29-33).

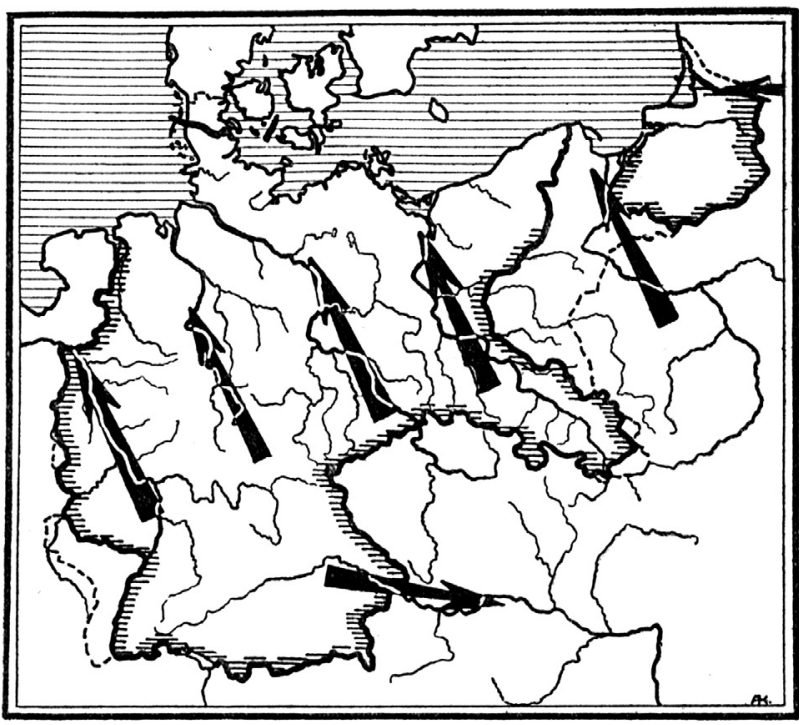

FIGURE 2: Germany: Parallelism of rivers as an obstacle to centralization (Obst, 1928, p. 33) 
In these two countries, rivers are oriented both to the north and to the south, and the capitals of these countries - Paris and Moscow - are situated at a core which is connected by waterways with various coasts and peripheral regions. In France, the Loire connects the Isle de France with the coast of the Atlantic Ocean, the Seine with the Channel, and waterways through Flanders connect the French capital with the North Sea, while the River Rhone provides the important link with the Mediterranean Sea. From Russia's Muscovite core lands towards the south, the Dnepr flows to the Black Sea, the Volga to the Caspian Sea; towards the north the Newa and a number of smaller rivers feed the Baltic Sea, and the Dvina feeds the White Sea. Obst regarded it as a proof of political intelligence that the Soviet government abandoned St. Petersburg, and turned back to Moscow as the traditional and best-suited capital of the empire (Obst, 1928, 30).

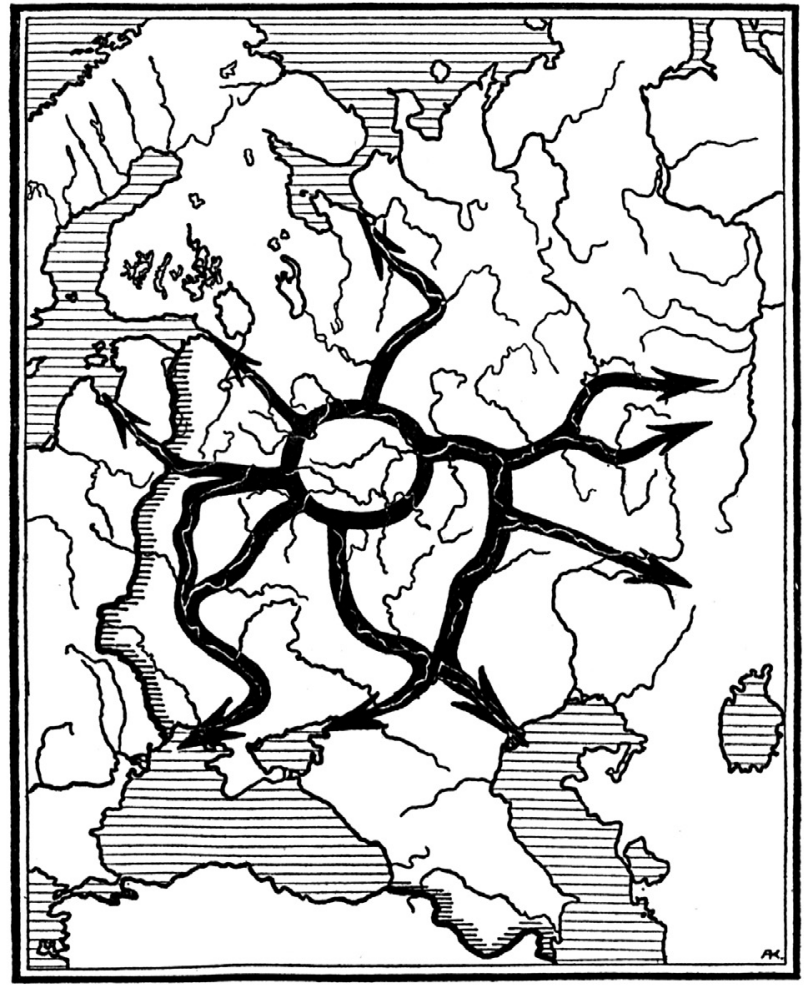

FiguRE 3: Russia: Rivers favouring centralized government from Moscow (Obst, 1928, p. 31)

If Max Barkhausen and Oliver Volckart have shown that political fragmentation was anything but detrimental to the growth of competitive industries, then a fresh look at the structuring of space by rivers might show that the fluvial system of Central Europe did in fact have an impact on the political and economic landscape, but in a positive way. The Holy Roman Empire did not have a capital (even if Vienna eventually became the Emperors' permanent residence), and its structure was federal rather than centralised. Mighty smaller actors, among them not only Dukes and Prince Electors, but also Hanseatic and Imperial Cities had to share power and influence. The Hanseatic Cities of Cologne, Bremen, Hamburg, Magdeburg on the River Elbe, Lubeck, Rostock, Stettin (today Szczecin), Thorn on the Vistula (today Toruń) and Danzig (today Gdańsk) did represent the commercial power which tended to concentrate at the estuaries of major navigable rivers, or further upstream. This system of urban and commercial power emerged during the Late Middle Ages, but remained in place into the Napoleonic period (and at some places beyond). It may well be the case that the characteristics of Central Europe's fluvial system were an obstacle to political centralisation - but an advantage to industry and trade. Thus, geography can probably help to explain why it was linen from Silesia rather than from Normandy and Brittany which filled the holds of many French slave ships - even if the French monarchy became centralised early on. Or help to explain why "all the Negroes and the poor White People [in the $18^{\text {th }}$ century British West Indies were] generally clothed with German linens" from Westphalia — and not with British or Irish produce (Newman, 1979: 198-199).

To this point, this is little more than a speculative thought, but it may encourage looking at larger geographic areas, yet with the critical awareness of how such strands of thought had been abused in the past. In doing so, interest in space would go beyond the scope of the urban, which had been the focus of most pioneers of the 'spatial turn', notably Henri Lefebvre, Edward Soja and David Harvey. (Schlögel, 2003: 60-71). It seems that post-war critical geography and social sciences, particularly in Germany, have more easily accepted the analysis of urban spaces than analysis of larger regions. The latter can be represented only on maps of larger scale. But looking at territorial maps, and even more so interpreting such maps, had become a highly dubious activity, in particular when they represented regions east of Germany's post-war borders. Even if the historian Hermann Aubin (1885-1969) and his brother Gustav Aubin (economist and economic historian, 1881-1938) did not rally with the most aggressive nationalists, anti-Semitism and a contempt for Slavonic people was part and parcel of their ideology. The subtitle of Gustav Aubin's exhaustive 1940 study on $15^{\text {th }}-16^{\text {th }}$ century German linen trade is telling: "A Contribution to the Industrial Colonisation of Eastern Central Germany". The geographers Erich Obst and Hugo Hassinger (1877-1952) are but two protagonists of a more explicit Nazi scholarship on Central Europe's ethnic and cultural borderlands, where German and Slavonic people met and mixed over centuries. Hassinger's 'Südostdeutsche Forschungsgemeinschaft' (created in Vienna in 1932), Obst's commitment with Haushofer's journal on 'Geopolitik', Hermann Aubin's and Karl Haushofer's close involvement with the interdisciplinary network of 'Ostforschung' (Burleigh, 2002) provide just a few examples of the numerous academics who contributed to legitimise and to prepare for the war which Germany waged on its eastern neighbours, with ethnic expulsions, political purges, ruthless exploitation, and genocides (Oberkrome, 1993; Haar, 2000). 
During the last decade, historians have developed a wider perspective on rivers, looking at their economic and ecological functions, at their role as cultural and/or national symbols, or objects of giant modernization projects (Rossiaud, 2007; Mauch and Zeller, 2008; Hausmann, 2009). Susanne Rau has provided an overview on this recent interest in waterways (Rau, 2010) and hinted to a tradition reaching back to Lucien Febvre's classic on the Rhine (Febvre, 1935). This author from the Annales School did not emphasise on the separating but on the uniting functions of this highly symbolic river. A new consideration of the role of Central and Eastern Europe's large waterways and rural regions in the process of early globalization may turn out to be very fruitful, but it must be accompanied by an awareness of the earlier uses and abuses of the categories of space.

\section{ACKNOWLEDGEMENT}

I am much indebted to my colleague Thomas Serrier for guiding me to the article and maps by Erich Obst, to my colleagues Anka Steffen and Reinhard Blänkner for their critical remarks, to the anonymous peer reviewer for the close read, and to Chris Smith for ironing my English.

\section{NOTES}

1 Archives Nationales, Paris, $\mathrm{F}^{12}$ 566-595 (Commerce et industrie, départements hanséatiques): Etat comparatif des importations des ports de France dans le port de Hambourg \& toutes les autres puissances en 1788.

\section{REFERENCES}

Aubin, Gustav and Kunze, Arno (1940) Leinenerzeugung und Leinenabsatz im östlichen Mitteldeutschland zur Zeit der Zunftkäufe: Ein Beitrag zur industriellen Kolonisation des deutschen Ostens. Kohlhammer, Stuttgart.

Barkhausen, Max (1958) "Staatliche Wirtschaftslenkung und freies Unternehmertum im westdeutschen und im nord- und südniederländischen Raum bei der Entstehung der neuzeitlichen Industrie im 18. Jahrhundert". Vierteljahrschrift für Sozial- und Wirtschaftsgeschichte, 86: 168-241.

Beckert, Sven (2014) Empire of Cotton. A Global History. Knopf, New York.

Bloch, Marc (1946) "Le problème de l'or au Moyen Age". Annales d'historie économique et sociale, 19: 1-34.

Boldorf, Marcel (2006) Europäische Leinenregionen im Wandel. Institutionelle Weichenstellungen in Schlesien und Irland (17501850). Böhlau Verlag, Köln.

British Parliamentary Papers (1975) House of Commons, Sessional Papers of the Eighteenth Century, Reports \& Papers 17421760, vol. 19. Report on Linen 1744, Wilmington.

Burleigh, Michael (2002) Germany Turns Eastwards. A Study of Ostforschung in the Third Reich. Pan Macmillan, London.

Cerman, Markus and Ogilvie, Sheilagh (1996) European Proto-Industrialization. An Introductory Handbook. Cambridge University Press, Cambridge.

Chamboredon, Robert (1991) "Une société de commerce languedocienne a Cadix: Simon et Arnail Fornier et $C^{\text {ie }}$ (Nov. 1768-Mars 1786)". In La burguesía de negocios en la Andalucía de la ilustración, vol. 2, edited by González García-Baquero, Antonio. Diputación provincial, Cadiz: 35-52.

Clarkson, Leslie (2003) "The Linen Industry in Early Modern Europe". In The Cambridge History of Western Textiles, edited by
Jenkins, David, Cambridge Universiy Press, Cambridge: 472493.

Collins, Brenda and Ollerenshaw, Philip (editors) (2003) The European Linen Industry in Historical Perspective. Oxford Universiy Press, Oxford.

David, Thomas and Etemad, Bouda and Schaufelbuehl, Janick Marina (2005) La Suisse et l'esclavage des Noirs. Antipodes, Lausanne.

Denzer, Jörg (2005) Die Konquista der Augsburger Welser-Gesellschaft in Südamerika (1528-1556). C.H. Beck, Munich.

Eltis, David and Richardson, David (2008) "A New Assessment of the Transatlantic Slave Trade." In Extending the Frontiers. Essays on the New Transatlantic Slave Trade Database, edited by Eltis, David and Richardson, David. Yale University Press, New Haven: 1-61.

Eltis, David (2001) "The Volume and Structure of the Transatlantic Slave Trade: A Reassessment." William and Mary Quarterly, 60: $17-46$.

Emmer, Piet C. (1998) The Dutch in the Atlantic Economy, 15801880. Trade, Slavery and Emancipation. Ashgate, Aldershot.

Febvre, Lucien (1935) Le Rhin. Problèmes d'histoire et d'économie. Armand Colin, Paris.

Fernand Braudel (1946) "Monnaies et civilisation, de l'or du Soudan à l'argent d'Amérique". Annales E.S.C., 1-1: 9-22.

Flügel, Axel (1993) Kaufleute und Manufakturen in Bielefeld. Sozialer Wandel und wirtschaftiche Entwicklung im proto-industriellen Leinengewerbe von 1680 bis 1850 . Verlag für Regionalgeschichte, Bielefeld.

Gary, A. T. (1935) The Political and Economic Relations of English and American Quakers (1750-1785). Oxford, unpublished PhD thesis.

Göttmann, Frank (1991) "Der Raum zwischen oberer Donau und Schweizer Alpen im 18. Jahrhundert: eine integrierte agrarischgewerbliche Wirtschaftsregion". Scripta Mercaturae, 25 (1/2): $1-40$.

Haar, Ingo (2000) Historiker im Nationalsozialismus. Deutsche Geschichtswissenschaft und der 'Volkstumskampf' im Osten. Vandenhoeck \& Ruprecht, Göttingen.

Häberlein, Mark (2006) Die Fugger. Geschichte einer Augsburger Familie (1367-1650). Kohlhammer, Stuttgart.

Häberlein, Mark (2008) "Jakob Fugger und die Kaiserwahl Karls V. 1519". In Die Fugger und das Reich. Eine neue Forschungsperspektive zum 500jährigen Jubiläum der ersten Fuggerherrschaft Kirchberg —_Weißenhorn, edited by Burckhardt, Johannes. Wißner-Verlag, Augsburg: 65-81.

Hausmann, Guido (2009) Mütterchen Wolga. Ein Fluss als Erinnerungsort vom 16. bis in frühe 20. Jahrhundert. Campus, Frankfurt/M.

Heiber, Helmut (1966) Walter Frank und sein Reichsinstitut für Geschichte des neuen Deutschlands. Deutsche Verlags-Anstalt, Stuttgart.

Henninger, Wolfgang (1993) Johann Jakob von Bethmann $1717-$ 1792. Kaufmann, Reeder und kaiserlicher Konsul in Bordeaux, 2 vols. Brockmeyer, Bochum.

Holt-Jensen, Arild (2004) Geography - History and Concepts: A Student's Guide. Sage, London.

Jenkins, David (editor) (2003) The Cambridge History of Western Textiles. Cambridge University Press, Cambridge.

Kellenbenz, Hermann (1964) "Der deutsche Außenhandel gegen Ausgang des 18. Jahrhunderts". In Forschungen zur Sozial- und Wirtschaftsgeschichte, edited by Lütge, Friedrich, vol. 8. Gustav-Fischer-Verlag, Stuttgart: 4-60.

Kellenbenz, Hermann and Walter, Rolf (1986) "Das Deutsche Reich 1350-1650". In Handbuch der europäischen Wirtschafts- und Sozialgeschichte, vol. 3, edited by Kellenbenz, Hermann. KlettCotta, Stuttgart: 822-889.

Kisch, Herbert (1968) Prussian Mercantilism and the Rise of the Krefeld Silk Industry. Variations upon an Eighteenth-Century Theme. American Philosophical Society, Philadelphia.

Kisch, Herbert (1959) "The Textile Industries in Silesia and the Rhineland: A Comparative Study in Industrialization." Journal of Economic History, 19: 541-564. 
Klein, Herbert S. (1999) The Atlantic Slave Trade. Cambridge University Press, Cambridge.

Kobayashi, Kazuo (2010) British Atlantic Slave Trade and East India Textiles, 1650s-1808. Osaka University Working Paper, Osaka.

Komlos, John (1989) Nutrition and Economic Development in the Eighteenth-Century Habsburg Monarchy. An Anthropometric History. Princeton University Press, Princeton.

Kossok, Manfred (1961) "Die Bedeutung des spanisch-amerikanischen Kolonialmarktes für den preußischen Leinwandhandel am Ausgang des 18. und zu Beginn des 19. Jahrhunderts". In Hansische Studien. Heinrich Sproemberg zum 70. Geburtstag, edited by Heitz, Gerhard and Unger, Manfred. Akademie-Verlag, Berlin: 210-218. Reprint in (2000) Ausgewählte Schriften. Kolonialgeschichte und Unabhängigkeitsbewegungen in Lateinamerika, vol. 1, edited by Middell, Matthias. Leipziger Univ.Verlag, Leipzig: 171-178.

Krawehl, Otto-Ernst (1977) Hamburgs Schiffs- und Warenverkehr mit England und den englischen Kolonien 1840-1860. Böhlau, Cologne - Vienna.

Kriedte, Peter and Medick, Hans and Schlumbohm, Jürgen (1981) Industrialization before Industrialization: Rural Industry in the Genesis of Capitalism. Cambridge University Press, Cambridge.

Kunze, Arno (1925) Die Verlagsbeziehungen des Nürnberger Handelskapitals zum sächsisch-böhmischen Leinwandproduktionsgebiete im 16. und 17. Jahrhundert. Halle, unpublished $\mathrm{PhD}$ thesis.

Kutz, Martin (1974) Deutschlands Außenhandel von der französischen Revolution bis zur Gründung des Zollvereins. Eine statistische Strukturuntersuchung zur vorindustriellen Zeit. Steiner, Wiesbaden.

Lefebvre, Henri (1974) Le droit à la ville, Paris 1968. La production de l'espace. Anthropos, Paris.

Makepeace, Margaret (1989) "English Traders on the Guinea Coast, 1657-1668: An Analysis of the East India Company Archive." History in Africa, 16: 237-284.

Małowist, Marian (1976) Konkwistadorzy portugalscy. Państ. Instytut Wydawniczy, Warsaw.

Małowist, Marian (2009a) "Levantine Trade with Eastern Europe in the 16th Century. Some Problems." In Western Europe, Eastern Europe and World Development, $13^{\text {th }}-18^{\text {th }}$ Centuries. Collection of Essays of Marian Matowist, edited by Batou, Jean and Szlajfer, Henryk. Brill, Leiden: 132-143.

Małowist, Marian (2009b) "The Foundations of European Expansion in Africa in the $16^{\text {th }}$ Century. Europe, Maghreb, and Western Sudan." In Western Europe, Eastern Europe and World Development, edited by Batou, Jean and Szlajfer, Henryk. Brill, Leiden: 339-369.

Małowist, Marian (2009c) "Portuguese Expansion in Africa and European Economy at the Turn of the $15^{\text {th }}$ Century." In Western Europe, Eastern Europe and World Development, $13^{\text {th }}-18^{\text {th }}$ Centuries. Collection of Essays of Marian Małowist, edited by Batou, Jean and Szlajfer, Henryk. Brill, Leiden: 373-393.

Mauch, Christof and Zeller, Thomas (editors) (2008) Rivers in History. Perspectives on Waterways in Europe and North America. Pittsburgh University Press, Pittsburgh.

Medick, Hans (1997) Weben und Überleben in Laichingen 16501900. Lokalgeschichte als Allgemeine Geschichte. Vandenhoeck \& Ruprecht, Göttingen.

Myška, Milan (1996) "Proto-Industrialization in Bohemia, Moravia and Silesia." In European Proto-Industrialization, edited by Ogilvie, Sheilagh and Cerman, Markus. Cambridge University Press, Cambridge: 188-207.

Newman, Karin (1979) Anglo-Hamburg Trade in the Late Seventeenth and Early Eighteenth Centuries. London, unpublished $\mathrm{PhD}$ thesis.

Niemann, Hans-Werner (2004) Leinenhandel im Osnabrücker Land. Die Bramscher Kaufmannsfamilie Sanders 1780-1850. Rasch, Bramsche.

Nolte, Burkhard (2004) Merkantilismus und Staatsräson in Preußen. Absicht, Praxis und Wirkung der Zollpolitik Friedrichs II. in Schlesien und in den westfälischen Provinzen (1740-1786). Verlag Herder-Institut, Marburg.
Oberkrome, Willi (1993) Volksgeschichte. Methodische Innovation und völkische Ideologisierung in der deutschen Geschichtswissenschaft 1918-1945. Vandenhoeck \& Ruprecht, Göttingen.

Obst, Erich (1928) "Zur Neugliederung des Deutschen Reiches". Zeitschrift für Geopolitik, 5-1: 27-40.

Overkamp, Anne Sophie (2014) "Of Tape and Ties: Abraham Frowein from Elberfeld and Atlantic Trade." In Europeans Engaging the Atlantic: Knowledge and Trade, c. 1500-1800, edited by Lachenicht, Susanne. Campus, Frankfurt/M. - New York:. 125150.

Pach, Zsigmond Pal (1990) "The East-Central European Aspect of the Overseas Discoveries and Colonization". In The European Discovery of the World and it Economic effects on Pre-industrial Society, 1500-1800, edited by Pohl, Hans, Steiner, Stuttgart.

Pétré-Grenouilleau, Olivier (1996) L'argent de la traite. Milieu négrier, capitalisme et développement: un modèle. Aubier, Paris.

Phillips, William D. Jr. (2004) "Sugar in Iberia." In Tropical Babylons: Sugar and the Making of the Atlantic World, 1450-1680, edited by Schwartz, Stuart B. University of North Carolina Press, Chapel Hill —- London: 27-41.

Pohl, Hans (1963) Die Beziehungen Hamburgs zu Spanien und dem spanischen Amerika in der Zeit von 1740 bis 1806. Steiner, Wiesbaden.

Radeff, Anne (1996) Du café dans le chaudron. Economie globale d'Ancien Régime, Suisse Occidentale, Franche-Comté et Savoie. Société d'histoire de la Suisse romande, Lausanne.

Rau, Susanne (2010) "Fließende Räume oder: Wie lässt sich die Geschichte eines Flusses schreiben?". Historische Zeitschrift, 291: 103-116.

Reininghaus, Wilfried (1995) Die Stadt Iserlohn und ihre Kaufleute. Ardey-Verlag, Münster.

Reininghaus, Wilfried (2008) Berg-, Hütten- und Hammerwerke im Herzogtum Westfalen im Mittelalter und in der frühen Neuzeit. Aschendorff, Münster.

Riello, Giorgio and Parthasarathi, Prasannan (editors) (2009) The Spinning World. A Global History of Cotton Textiles, 12001850. Oxford University Press, Oxford.

Roberts, Richard (1992) Schroders. Merchants and Bankers. Macmillan, London.

Rossiaud, Jacques (2007) Le Rhône au Moyen Âge. Histore et représentations d'un fleuve européen. Aubier, Paris.

Ryder, A. F. C. (1959) "An Early Portuguese Trading Voyage to the Forcados River." Journal of the Historical Society of Nigeria, 1-4: 294-321.

Salz, Arthur (1913) Geschichte der Böhmischen Industrie in der Neuzeit. Duncker \& Humblot, Munich - Leipzig.

Sandgruber, Roman (1983) "Innerfamiliale Einkommens- und Konsumaufteilung: Rollenverteilung und Rollenverständnis in Bauern-, Heimarbeiter und Arbeiterfamilien Österreichs im 18., 19. und frühen 20. Jahrhundert”. In Ehe, Liebe, Tod. Zum Wandel der Familie, der Geschlechts- und Generationsbeziehungen in der Neuzeit, edited by Borscheid, Peter and Teuteberg, Hans J. F. Coppenrath, Münster: 135-149.

Saugera, Eric (1995) Bordeaux port négrier. Chronologie, économie, idéologie, $X V I I^{\mathrm{e}}-X I X^{\mathrm{e}}$ siècles. Karthala, Biarritz - Paris.

Schilling, Heinz (1983) "Innovation through Migration: The Settlements of Calvinistic Netherlanders in Sixteenth and Seventeenth Century Central and Western Europe." Histoire Sociale - Social History, 31: 7-33.

Schmitz, Edith (1967) Leinengewerbe und Leinenhandel in Nordwestdeutschland (1650-1850). Rheinisch-Westfälisches Wirtsch.-Archiv, Cologne.

Schneider, Jürgen (1998) "Die neuen Getränke Schokolade, Kaffee und Tee (16.-18. Jahrhundert)". In Prodotti e Tecniche d'Oltremare nelle Economie Europee Secc. XIII-XVIII. Atti della 'Ventinovesima Settimani di Studi' 14-19 aprile 1997, edited by Simonetta Cavaciocchi. Istituto Internazionale di Storia Economica 'F. Datini', Florence: 541-590.

Schneider, Jürgen and Krawehl, Otto-Ernst and Denzel, Markus A. (2001) Statistik des Hamburger seewärtigen Einfuhrhandels im 18. Jahrhundert. Scripta Mercaturae Verlag, St. Katharinen. 
Schulte Beerbühl, Margrit (2007) Deutsche Kaufleute in London. Welthandel und Einbürgerung (1600-1818). Oldenbourg, Munich.

Schulte Beerbühl, Margrit (2010) "Merchant Empires: Mercaderes hamburgueses en Londres y sus redes de comercio internacional (1660-1815)". In Comunidades transnacionales, edited by Crespo Solana, Ana, Doce Calles, Madrid.

Schulte, Aloys (1923) Geschichte der Großen Ravensburger Handelsgesellschaft 1380-1530, vol. 3. DVA, Stuttgart - Berlin.

Schlögel, Karl (2003) Im Raume lesen wir die Zeit. Über Zivilisationsgeschichte und Geopolitik. Carl Hanser, Munich.

Soja, Edward W. (1989) Thirdspace. Journeys to Los Angeles and Other Real-and-Imagined Places. Blackwell, London - New York.

Stols, Eddy (2001) "Humanistas y jesuitas en los negocios brasileños de los Schetz, grandes negociantes de Amberes y banqueros de Carlos V'. In Carlos V y la quiebra del humanismo politico en Europa (1530-1558), edited by Millán, José Martinez, vol. 4. Sociedad Estatal Para la Conmemoracion de los Centenarios de Felipe II y Carlos V, Madrid: 29-47.

Stols, Eddy (2004) "The Expansion of the Sugar Market in Western Europe." In Tropical Babylons: Sugar and the Making of the Atlantic World, 1450-1680, edited by Schwartz, Stuart B. University of North Carolina Press, Chapel Hill_ London: 237-288.

Thésée, Françoise (1972) Négociants bordelais et colons de SaintDomingue. Liaisons d'habitation. La maison Henry Romberg, Babst \& Cie. 1783-1793. Société française d'histoire d'outremer, Paris.

Torres Ramírez, Bibiano (1973) La compañia gaditana de negros. Escuela de Estudios Hispano-Americanos, Sevilla.

Veyrassat, Béatrice (1982) Négociants et fabricants dans l'industrie cotonnière suisse, 1760-1840. Aux origines financières de l'industrialisation. Payot, Lausanne.

Vieira, Alberto (2004) "Sugar Islands. The Sugar Economy of Madeira and the Canaries, 1450-1650." In Tropical Babylons, edited by Schwartz, Stuart B. University of North Carolina Press, Chapel Hill — London: 42-84.

Vilar, Pierre (1962) La Catalogne dans l'Espagne moderne. Recherches sur les fondements économiques des structures nationales, vol. 3. S.E.V.P.E.N., Paris.

Viñas, Paloma Pastor Rey de (1994) Historia de la Real Fábrica de Cristales de San Ildefonso durante la época de la ilustración (1727-1810). Editorial CSIC - CSIC Press, Madrid.

Volckart, Oliver (1999) "Politische Zersplitterung und Wirtschaftswachstum im Alten Reich, ca. 1650-1800". Vierteljahrschrift für Sozial- und Wirtschaftsgeschichte, 86: 1-38.
Vries, Jan de (1984) European Urbanization 1500-1800. Methuen \& Co, London.

Wallerstein, Immanuel (1974) The Modern World System: Capitalist Agriculture and the Origins of the European World-Economy of the Sixteenth Century, vol. 1. Academic Press, New York - London.

Weber, Klaus (1999) “Les livres douaniers de l'Amirauté de Hambourg au XVIII ${ }^{\mathrm{e}}$ siècle, une source de grande valeur encore inexploitée". Bulletin du Centre d'Histoire des espaces atlantiques, nouvelle série, 9: 93-126.

Weber, Klaus (2004) Deutsche Kaufleute im Atlantikhandel 16801830: Unternehmen und Familien in Hamburg, Cadiz und Bordeaux. C.H. Beck, Munich.

Weber, Klaus (2009) "Deutschland, der atlantische Sklavenhandel und die Plantagenwirtschaft der Neuen Welt (15. bis 19. Jahrhundert)". Journal of Modern European History, 7 (1): 37-67.

Weber, Klaus (2010) "Intercambios mercantiles y culturales: Comerciantes alemanes en Cádiz, 1680-1830". In Comunidades transnacionales. Colonias de mercaderes extranjeros en el Mundo Atlántico (1500-1830), edited by Crespo Solana, Ana, Doce Calles, Madrid: 101-122.

Wehler, Hans-Ulrich (1987) Deutsche Gesellschaftsgeschichte, vol. 1. C.H. Beck, München.

Williams, Eric (1994) Capitalism and Slavery. Univ. of North Carolina Press, Chapel Hill - London.

Wischermann, Clemens (1992) Preußischer Staat und westfälische Unternehmer zwischen Spätmerkantilismus und Liberalismus. Böhlau, Vienna - Cologne.

Zeuske, Michael and Ludwig, Jörg (1995) "Amerikanische Kolonialwaren in Preußen und Sachsen: Prolegomena”. Jahrbuch für Geschichte von Staat, Wirtschaft und Gesellschaft Lateinamerikas, 32: 257-301.

Zeuske, Michael (1995) "Die sächsischen Mitglieder der RheinischWestindischen Compagnie”. In Sachsen und Lateinamerika. Begegnungen in vier Jahrhunderten, edited by Zeuske, Michael; Schröter, Bernd and Ludwig, Jörg. Vervuert, Frankfurt/M.: 164-200.

Zimmermann, Alfred (1885) Blüthe und Verfall des Leinengewerbes in Schlesien. Gewerbe- und Handelspolitik dreier Jahrhunderte. W.G. Korn, Breslau.

Zorn, Wolfgang (1961) "Schwerpunkte der deutschen Ausfuhrindustrie im 18. Jahrhundert”. Jahrbücher für Nationalökonomie und Statistik, 173: 421-447.

Zylberberg, Michel (1993) Une si douce domination: Les milieux d'affaires français et l'Espagne vers 1780-1808. Comité pour l'Histoire Économique et Financière de la France, Paris. 